\title{
IDENTIDADE DO PROFISSIONAL DA EDUCAÇÃO ESPECIAL: construção na escola indígena
}

\author{
Selma Maria Cunba Portela \\ Roseli Bernardo Silva dos Santos
}

\section{Resumo}

Esta análise é resultado de um trabalho acadêmico vinculado ao programa de pós-graduação em educação com a linha de pesquisa da educação intercultural. Nessa perspectiva se intitulou Identidade profissional do professor que atua na sala de recurso multifuncional: um estudo a partir de uma escola indigena em Roraima, com o objetivo de analisar o processo de construção da identidade profissional do professor da sala de recurso multifuncional que atua no contexto da escola indígena em Roraima (RR). A pesquisa foi realizada em parceria com um grupo de professores e chefes de divisões da Secretaria de Estado de Educação e Desporto (SEED), de abordagem qualitativa, compreendendo pesquisa bibliográfica, entrevistas e análise documental. Nesse recorte apresentaremos fragmentos dos resultados e discussões, focando: perfil dos professores da educação especial que atuam na escola indígena; análise interpretativa da ideia de diferença nos distintos contextos sociais; atendimento educacional especializado como processo de inclusão; a escola e alunos indígenas. Observa-se que a identidade do profissional da educação especial que atua na escola indígena é constituída de elementos advindos do contexto pessoal, coletivo e da experiência educativa. Entretanto, deve-se considerar a cultura de cada docente indígena. Constata-se que os professores que atuam na sala de recurso multifuncional na escola indígena, sob a ótica da inclusão, em meio as dificuldades, à insegurança e ansiedades, sentem-se despreparados para o exercício da articulação que visa à inclusão de alunos com necessidades educacionais especiais no espaço escolar.

Palavras-chave: professor; identidade profissional; educação especial; inclusão.

\section{IDENTITY OF THE SPECIAL EDUCATION PROFESSIONAL:} developing in the indigenous school

\begin{abstract}
This analysis is the result of academic work linked to the graduate program in education with the line of research on intercultural education. In this perspective, it was entitled Professional Identity of the Teacher who works in the Multifunctional Resource Room: a study from an indigenous school in Roraima, with the objective of analyzing the process of building the professional identity of the teacher of the multifunctional resource room who works in the context of the indigenous school in Roraima (RR). The research was carried out in partnership with a group of teachers and heads of divisions of the State Secretariat of Education and Sport (SEED), with a qualitative approach, which included bibliographic research, interviews and document analysis. In this section we will present fragments of the results and discussions focusing on: profile of special education teachers working in the indigenous school, interpretative analysis of the idea of difference in diverse social contexts and specialized educational assistance as an inclusion process: school and indigenous students. It is observed that the identity of the special education professional who works in the indigenous school is constituted of elements arising from the personal, collective context and the educational experience, however, the culture of each indigenous teacher must be considered. Noting that the teachers who work in the multifunctional resource room at the indigenous school from the perspective of inclusion, amid difficulties, insecurity and yearnings, feel unprepared to exercise full articulation for the inclusion of students with educational needs specials in the school ambience.
\end{abstract}

Keywords: teacher; professional identity; special education; inclusion. 


\section{IDENTIDAD DEL PROFESIONAL DE EDUCACIÓN ESPECIAL:} construcción en la escuela indígena

\section{Resumen}

Este análisis es el resultado del trabajo académico vinculado al programa de posgrado en educación con la línea de investigación sobre educación intercultural. En esta perspectiva, se tituló Identidad profesional del maestro que trabaja en la sala de recursos multifuncionales: un estudio de una escuela indígena en Roraima, con el objetivo de analizar el proceso de construcción de la identidad profesional del maestro de la sala de recursos multifuncionales que trabaja en el contexto de la escuela indígena en Roraima (RR). La investigación se llevó a cabo en asociación con un grupo de maestros y jefes de divisiones de la Secretaría de Estado de Educación y Deporte (SEED), con un enfoque cualitativo, que incluyó investigación bibliográfica, entrevistas y análisis de documentos. En esta sección presentaremos fragmentos de los resultados y debates centrados en: el perfil de los maestros de educación especial que trabajan en la escuela indígena, el análisis interpretativo de la idea de la diferencia en varios contextos sociales y la asistencia educativa especializada como un proceso de inclusión: la escuela y los estudiantes indígenas. Se observa que la identidad del profesional de educación especial que trabaja en la escuela indígena se compone de elementos derivados del contexto personal, colectivo y de la experiencia educativa, sin embargo, la cultura de cada maestro indígena debe ser considerada. Observando que los maestros que trabajan en la sala de recursos multifuncionales en la escuela indígena desde la perspectiva de la inclusión, en medio de dificultades, inseguridad y anhelos, no se sienten preparados para ejercer una articulación completa para la inclusión de estudiantes con necesidades educativas especiales en el espacio escolar.

Palabras clave: profesor; identidad profesional; educación especial; inclusión.

\section{INTRODUÇÃO}

A educação escolar indígena tem em suas raízes históricas travado muitos desafios, entre estes as imposições do sistema educacional desde o período colonial, às quais foi submetida para atender a aquisição de valores da sociedade ocidental. Apesar das imposições, a educação escolar é empoderada pelos indígenas como instrumento de resistência, e os processos de inclusão nas escolas indígenas tornam-se mais um desafio. Assim, o objetivo desse recorte, é apresentar uma análise baseada no entendimento da política de educação especial na perspectiva da educação inclusiva. Contribui-se, dessa forma, para outros estudos na área, uma vez que a temática requer aprofundamento, de modo a colaborar com a inclusão no espaço escolar indígena.

É fato que a prática de infanticídio em algumas etnias / aldeias indígenas durou bastante tempo. Crianças que apresentavam alguma deficiência, nem sempre chegavam a adentrar as escolas como sujeitos de direitos. A inclusão dessas crianças no espaço escolar faz parte de uma recente agenda de lutas dos povos indígenas, que vem ganhando força na sua concretização, desde a matrícula até o acesso ao conhecimento advindo de uma proposta inclusiva que atenda suas necessidades.

Sabemos que a inclusão de todos no espaço escolar e em outros espaços sociais ainda requer luta contra os sistemas que deveriam ser provedores da educação para todos. Constatam-se, nas realidades provenientes do campo de pesquisas, os entraves para a efetiva inclusão, impondo-nos reflexões sobre formas de lutas que necessitam ser travadas, principalmente no atual momento político, em que forças governamentais se entrelaçam, impondo um modelo conservador e autoritário de poder, que tem se refletido no ambiente educacional de forma negativa e desalentadora.

Ficou evidente que os conjuntos discursivos não se apresentam como unidade, por isso, destacaremos elementos importantes que contribuem para entender a construção da identidade do professor de atendimento educacional especializado (AEE): a) a educação especial no contexto da 
educação escolar indígena; b) análise interpretativa da ideia de diferença nos distintos contextos sociais; c) perfil dos professores da educação especial que atuam na escola indígena; d) atendimento educacional especializado como processo de inclusão: escola e alunos indígenas.

\section{EDUCAÇÃO ESPECIAL NO CONTEXTO DA EDUCAÇÃO ESCOLAR INDÍGENA}

A educação especial se tornou objeto de discussão há bastante tempo, mais precisamente a partir do século XIX, quando se deram as primeiras iniciativas de novas intenções na educação de indivíduos com deficiência. Na Constituição de 1988, Artigo 205, a educação é entendida como um direito de todos, garantindo o pleno desenvolvimento da pessoa, o exercício da cidadania e a qualificação para o trabalho. No Artigo 208, inciso I, estabelece a "[...] igualdade de condições de acesso e permanência na escola" como um dos princípios para o ensino e garante, como dever do Estado, a oferta do atendimento educacional especializado, preferencialmente na rede regular de ensino.

A implantação da educação especial, no Brasil, deu-se a partir de influências de movimentos estrangeiros, período em que o Brasil ainda era Colônia Portuguesa. A França era o país onde se localizava a centralidade da cultura e educação. Os primeiros profissionais a atuarem nessas instituições tinham formação na área médica. Era comum a presença de médicos à frente de instituições educacionais.

A atual Lei de Diretrizes e Bases da Educação Nacional (LDB) n. 9.394/96 define por educação especial a modalidade de educação escolar oferecida, preferencialmente na rede regular de ensino, para educandos portadores de necessidades especiais. Já a educação inclusiva constitui um paradigma educacional fundamentado na concepção de direitos humanos, que conjuga igualdade e diferença como valores indissociáveis, e que avança em relação à ideia de equidade formal, ao contextualizar as circunstâncias históricas da produção da exclusão dentro e fora da escola (BRASIL, MEC, 2008).

Enquanto a exclusão pode ser entendida como um ato que priva ou exclui alguém de participar de determinado contexto, como o contexto educacional em sentido pleno, a inclusão é um processo que se direciona à diversidade social, incluindo todos em todos os espaços, o que engloba discentes deficientes ou não nos diferentes aspectos, participando tanto no âmbito educacional como em outras instâncias sociais.

A educação especial é compreendida como uma modalidade de educação que atua como um serviço de atendimento educacional especializado no espaço da escola, ou em outros espaços indicados pelas Diretrizes da Política de Educação Especial, numa perspectiva inclusiva. Um serviço de mediação para a educação inclusiva na escola, pois permite articulação mútua em todos os ambientes.

Em Roraima, a educação especial já existe desde a década de 1970, período da implantação da Divisão de Educação Especial, pela secretaria de educação do estado. Somente muito tempo depois, com a instalação das salas de recursos nas escolas indígenas é que o público da educação especial indígena vem sendo contemplado com este serviço.

A efetivação desse serviço nem sempre pode ser comprovada como estabelece a Resolução CEE/RR n. 07(2009), que ressalta a necessidade de desenvolver, no sistema estadual de educação de Roraima, políticas educacionais inclusivas que garantam o cumprimento do direito à educação para todos os alunos, sem discriminação ou segregação, e um amplo respeito às necessidades educacionais para que estes alunos possam apresentar, no processo de aprendizagem, o desenvolvimento escolar como um todo. No entanto, tais políticas caminham paulatinamente no sentido da concretização das ações do estado em promover a inclusão de todos, fazendo parte 
desse processo uma formação que contemple todos os professores, sem distinção de raça, religião, cultura ou etnia.

As Diretrizes da Política de Educação Especial, numa perspectiva inclusiva (BRASIL, MEC, 2008) destacam a interface da educação especial na educação indígena, assegurando recursos adaptados, tecnologia assistiva e estrutura arquitetônica inclusiva. Nesse contexto, o atendimento educacional especializado é um apoio para complementar e suplementar o ensino, diminuindo barreiras para a inclusão dos alunos com necessidades educacionais especiais (NEE).

Afirma-se que vivemos numa sociedade democrática que tem, por definição, a pluralidade, o convívio e a interlocução na diversidade. Está previsto na legislação o direito de participar nos espaços e processos comuns de ensino e aprendizagem realizados pela escola. Assim, as políticas educacionais devem estar compatíveis com esses pressupostos que orientam para o acesso pleno e condições de equidade no sistema de ensino.

A Constituição Federal de 1988 adotou como princípio "[...] a igualdade de condições para o acesso e permanência na escola", compreendido como a efetivação do objetivo republicano de "[...] promover o bem de todos, sem distinção de raça, sexo, cor, idade e quaisquer outras formas de discriminação"; prevê "[...] uma sociedade com escolas abertas a todos, em qualquer etapa ou modalidade, bem como o acesso a níveis mais elevados de ensino" (BRASIL, MEC / SEESP, 2006).

A modalidade de educação especial deve perpassar todas as etapas e níveis de ensino, entretanto, isso ainda não é visível como ditam os princípios da lei maior; a própria educação indígena sofre com sua ausência desde seus primórdios. Como uma educação específica, requer preocupações com seus costumes e sua cultura.

No estado de Roraima, a educação especial tem trajetória peculiar em relação ao restante do país: enquanto na maior parte dos estados brasileiros as instituições educacionais e de assistência às pessoas com deficiência nasceram da organização de familiares de crianças com deficiências, em Roraima tais instituições nascem do poder público, em maioria atendendo a solicitações da comunidade.

Informações advindas da pesquisa de Magalhães (2003), em monografia de pós-graduação lato sensu, em que estuda o perfil de professores que atuam na Escola Estadual de Educação Especial de Boa Vista, relatam a criação na Secretaria de Educação do (ainda) Território Federal de Roraima, de uma Coordenação de Educação Especial em 1975, sendo dado início ao atendimento a alunos com deficiência mental e auditiva. Isto ocorreu em instalações da Escola Monteiro Lobato, no ano de 1976, há 44 anos. Lá, de forma precária, iniciaram-se as atividades em sala de aula, nas quais os alunos eram atendidos por professoras pioneiras nessas atividades, Carlota Maria de Figueiredo Rodrigues e Clotilde Parima Rodrigues, que exerciam as mais variadas funções, como a grande maioria dos profissionais de educação daquela época.

É compreensível dizer que a cultura indígena é específica, o que se reafirma em suas práticas de vivência em comunidade. Sabe-se que essa cultura vem sofrendo alterações pela forma de atuar de seu povo, mas, no entanto, não se pode afirmar que tais mudanças são advindas exclusivamente de influências da civilização não índia. Sabe-se, também, que em determinadas comunidades indígenas, por longo período, o indivíduo que nascia com deficiência era descartado como um ser inservível.

Segundo Barreto (2016), a prática tradicional nociva de infanticídio indígena, que estava presente em alguns povos indígenas brasileiros, acontecia principalmente com crianças que apresentavam algum tipo de deficiência, com gêmeos, filhos de mãe solteira, ou por seleção de sexo. Um tema pouco discutido, porque era considerado tabu. Somente em 2005, quando se divulgaram diversas histórias de crianças sobreviventes, e quando surgiu, em 2006, a ONG AtiniVozpela vida, que passou a acolher famílias indígenas que discordavam da prática e desejavam salvar 
a vida de seus filhos, contrariando inclusive órgãos governamentais, foi que o tema passou a ser mais discutido. Ainda conforme pesquisa realizada por Barreto (2016), em 2007 houve a propositura do Projeto de Lei n. 1.057, que tinha como objetivo abordar as práticas tradicionais nocivas, bem como outras iniciativas nesse sentido.

No caso dos indígenas, a prática se dava por motivos culturais. Subentende-se que o efetivar dessa prática ignorava o ser humano, por considerar um defeito sua deficiência. $\mathrm{O}$ ato de matar ou não, nem sempre sob o argumento de não servir realmente, mas de atrapalhar a dinâmica, o cotidiano da comunidade era ou é ainda considerado, por alguns grupos indígenas, parte do ritual da cultura.

Com o advento de políticas públicas mais consistentes e ampliação do acesso à educação, a prática de infanticídio vem diminuindo substancialmente, dando margem à sobrevivência de crianças índias que passam a ter a oportunidade de conviver em suas comunidades e acesso aos direitos que lhe conferem a legislação brasileira, no que se refere especificamente à educação e, principalmente, à educação especial, como determina a política específica para esse fim.

A educação especial na educação indígena, em Roraima, tem sua origem a partir das discussões refletidas pelos acadêmicos da Universidade Federal de Roraima. Desde então se intensificaram os debates, no sentido de implementação dessa modalidade de educação. Tais discussões se estenderam à I Conferência Nacional de Educação Escolar Indígena (CONNEI), ocorrida na cidade de Luziânia, em Goiás (GO), de 16 a 20 de novembro de 2009. Dentre as intensas discussões contidas no III eixo temático sobre Política, Gestão e Financiamento da Educação Escolar Indígena, destaca-se a política linguística, quando se definiu: “[...] criar um programa específico para atender os alunos portadores de necessidades especiais, garantindo a contratação e capacitação de professores indígenas, para que tenham condições de identificar e atender essa demanda". O eixo ainda previa a disponibilização de materiais didáticos e equipamentos necessários ao atendimento especializado aos referidos alunos. Isto ficou estabelecido de modo a garantir o serviço às regiões do país em que há presença de povos indígenas.

O documento oficial da I Conferência, de âmbito nacional, traz garantias desse serviço, ficando estendidas em sua organização específica pelos dispositivos locais de cada estado, provendo assim o direito, em tese, desses estudantes não só ao acesso, mas à permanência no sistema de ensino vigente. Outro documento importante que trata da questão de garantias é o Regimento Unificado para Escolas Indígenas do sistema estadual de ensino, que definiu a oferta da educação especial:

Art. $9^{\circ}$ A oferta da Educação Especial nas escolas indígenas do Sistema Estadual deve proporcionar aos discentes com necessidades especiais educacionais mentais, visuais, auditivos, físicos e múltiplos, de conduta típica, de síndromes e altas habilidades / superdotação, recursos e atendimentos especializados, que contemplem a aquisição de habilidades e competências, favorecendo o processo de ensino e de aprendizagem e sua inclusão nas classes regulares.

Parágrafo Único: Os atendimentos serão auxiliados pela coordenação de Educação Especial com o currículo regular das escolas em qualquer nível ou modalidade, observando as necessidades específicas de cada discente podendo os mesmos serem encaminhados para o atendimento nos centros portadores de recursos humanos e materiais adequados, caso seja necessário. (RORAIMA REGIMENTO ESTADUAL, 2011, p. 10)

Os dispositivos já existem para determinar o que deveria ser realizado nessa modalidade de educação, no entanto, contrapõe-se à realidade que é bem diferente como tudo o que se refere a essa clientela. Além do regimento unificado estadual para as escolas indígenas, o Plano Estadual de Educação (PEE/RR, 2015) vem estabelecer para a educação indígena, em suas estratégias, no item 
10: "[...] condições para inclusão das crianças com deficiência, com apoio de especialistas e cuidadores, definindo o número máximo de crianças por sala, imóvel, mobiliário, material pedagógico adaptado, espaço físico acessível, orientação, supervisão e alimentação".

É evidente que os esforços por parte dos indígenas na luta pela garantia de direitos têm avançado, principalmente quando se constata que a Política de Educação Especial na perspectiva da educação inclusiva deixa evidente que "[...] os sistemas de ensino devem organizar as condições de acesso aos espaços, aos recursos pedagógicos e à comunicação que favoreçam a promoção da aprendizagem e a valorização das diferenças, de forma a atender as necessidades educacionais dos alunos". Para que se efetive a aprendizagem, "[...] a acessibilidade deve ser assegurada mediante a eliminação de barreiras arquitetônicas, urbanísticas, na edificação - incluindo instalações, equipamentos e mobiliários - e nos transportes escolares, bem como as barreiras nas comunicações e informações" (BRASIL, MEC / SEESP, 2008).

A Lei que estabelece as diretrizes para a educação em nosso país, a LDB n. 9.394/96, orientou a redação da Lei n. 12.796 de 2013 que, no Artigo 59, determina que os sistemas de ensino assegurarão aos educandos com deficiência, transtornos globais do desenvolvimento e altas habilidades ou superdotação, I - currículos, métodos, técnicas, recursos educativos e organização específica, para atender a suas necessidades. Tudo isso ainda não faz parte da realidade da escola urbana, muito menos da escola indígena. $\mathrm{O}$ atendimento educacional especializado está longe de ser uma realidade no que tange a atender as especificidades do público presente na escola indígena. A realidade das dificuldades que se verifica na zona urbana, claro, não é igual à da escola do campo, entretanto, são dificuldades semelhantes.

A mesma Lei que rege as normativas para a escola urbana, rege para as escolas do campo, porém, não especifica, no caso das escolas do campo, particularmente a indígena, a necessidade de atendimento específico ao educando, que respeite sua cultura, sua realidade e suas formas de educação. Pode ser que as interpretações sejam diferentes como as necessidades de cada público, o que não se justifica quando o atendimento educacional especializado não atende o aluno indígena, por exemplo, de forma bilíngue, ou seja, não assegura a ele o direito de aprender tanto em Língua Portuguesa como em sua língua indígena.

O inciso IV, ainda do Artigo 59 da LDB, trata da formação: professores com especialização adequada em nível médio ou superior, para atendimento especializado, bem como professores do ensino regular capacitados para a integração desses educandos nas classes comuns. Segundo Ló (2010) uma escola inclusiva despreza a cultura da uniformidade, por meio da qual impera um ambiente autocrático, um currículo fragmentado e com ênfase no ensino. Chama atenção para pontos importantes no que se refere ao respeito à diversidade, quando explica que educação inclusiva e diversidade: "[...] são pontos inseparáveis um do outro e nos fazem voltar o olhar para o aluno com suas diferenças individuais, aptidões, motivações, interesses e experiências de vida que têm grande influência no processo de aprendizagem, que é único de cada pessoa”. (LÓ, 2010, p. 130).

Uma das definições dada pelo MEC à educação inclusiva refere-se a novas relações pedagógicas, centradas nos modos de aprender das diferentes crianças e jovens, sendo relações sociais que valorizam a diversidade em todas as atividades, espaços e formas de convivência de trabalho. Aqui centra-se o objetivo na forma de ensinar e aprender, respeitando as relações sociais diversas e valorizando as potencialidades expressas.

A escola indígena precisa tornar-se inclusiva e, para isso, as características individuais não podem ser ignoradas, seguindo a lógica de que suas práticas também seguem padrões da sociedade moderna, práticas que incluem uns e excluem outros. Para se consolidar como escola inclusiva, se movimenta em torno de princípios como: acessibilidade e permanência; estas, no caso da permanência do aluno deficiente, só serão possíveis se as condições foram dispensadas para que o 
seu desenvolvimento aconteça. Condições essas que tendem a produzir a pirâmide de sustentação para que a educação inclusiva se torne realidade.

Nesse viés, a educação nas últimas décadas tem diretrizes expressas em declarações e acordos internacionais, assim como na referida LDB de 1996, que têm provocado mudanças no movimento educacional inclusivo, o qual pressupõe o desenvolvimento de uma nova cultura na escola - cultura esta que exclui a homogeneização. Tradicionalmente, a escola vem realizando seu trabalho dando ênfase na homogeneização, relacionada à ideia de expansão de ofertas educacionais para todos. Como sabiamente destaca Ló (2010), com o intuito de atender a demandas da Revolução Industrial, preparando mão de obra para a produção e desenvolvendo conhecimentos e habilidades comuns, a escola valida naturalmente a ideia de semelhança e afasta os diferentes. Durante bastante tempo, este foi o papel da escola: desenvolver suas atividades numa perspectiva homogeneizada, excluindo os diferentes nos diversos aspectos educacionais.

Adotar uma nova postura enquanto escola, é o mesmo que pensar a escola numa nova perspectiva cultural, deixando determinados hábitos, os quais parecem estar enraizados, e iniciar um novo momento na história, em que se priorize trabalhar novas concepções, atitudes e ideais de educação. A diferença na escola é considerada inexistente, pois as práticas escolares reafirmam determinadas doutrinas, apoderando-se de práticas excludentes, que fazem do espaço escolar um ambiente de transferência de conhecimento e atitudes, ao invés de transformá-los.

A presença da educação especial na escola indígena é recente, e tal serviço ainda não é desenvolvido de forma que atenda necessidades dos alunos que são seu público. Constata-se essa realidade quando apenas 21 escolas indígenas dispõem de espaço para a sala de recursos multifuncional e, consequentemente, para promover a inclusão dos sujeitos nessas comunidades escolares. A realidade da educação inclusiva na escola indígena é ainda uma não-realidade, o "ainda" corresponde ao sentimento de esperança, a partir da luta para sua concretização. Pautando-se em Gadotti (2012), a educação só tem sentido na medida em que é concebida como ação visando à participação e autonomia. É um processo de transformação do indivíduo e da sociedade e a escola não pode se ausentar das lutas sociais mais globais. Assim entendendo, a escola deve fazer parte de todo e qualquer processo de luta social que corresponde ao benefício coletivo, ou seja, a escola indígena está em processo de luta para a efetivação da educação inclusiva.

Como é visível, o processo de luta por uma educação que atenda realmente cada estrutura social é constante. Diante disso, estabelece o objetivo da educação numa perspectiva de democratização da sociedade, como defende Gadotti (2012, p. 126), para quem o modelo de autogestão permite "[...] formar o homem para assumir-se integralmente, portanto, autogovernarse e governar [...]. Só que hoje, com a divisão da sociedade, só uma parcela está sendo formada para o comando, só a elite está se preparando para a autogestão". Esta formação precisa atingir o coletivo.

Talvez haja reflexões espontâneas no sentido de "como é possível formar indivíduos com necessidades especiais para a autogestão?” Talvez seja um tanto contraditório. Pode ser analisado não do ponto de vista individual, como proposta de formação, mas também do coletivo, quando a escola, enquanto espaço social em que a liberdade e a autonomia implicam ação comum - a solidariedade. O homem não pode ser visto de forma isolada. Seguindo tal concepção, Deville, traduzindo o capital de Marx (2013), explica:

O Homem é para o homem um auxiliar necessário; a comunidade de ação que tende por meio de funções diferentes, porém respectivamente indispensáveis, a realização de um fim comum, o bem-estar, deve completar-se evidentemente com a comunidade de vantagens. A solidariedade, que tem sido sucessivamente familiar, comunal, nacional, tende a ser internacional. Desde esse momento, a faculdade que possui o homem de operar só, de ser em absoluto independente 
da ação dos demais, em suma, a autonomia tão obstinadamente glorificada, se não fosse irrealizável, mercê da evolução econômica que domina todas as relações humanas, seria um retrocesso, uma diminuição de força, isto é, de liberdade, para o indivíduo, em lugar de ser adicionamento. (DEVILLE, 2013, p. 31).

Em qualquer das lutas, o homem é mais forte ao solidarizar-se com o outro, na união das forças consegue tornar-se mais independente, livre nas suas conquistas. Isto é, reafirmar-se como ser social, exige interagir com o outro e, não obstante, solidarizar-se com suas necessidades. $\mathrm{O}$ capitalismo, em seu agir contraditório, se concretiza quando a atual sociedade do capital sobrepõese à cultura dominante de produção do trabalho individual e competitivo em que o ser humano está sendo moldado. Dessa forma, é imprescindível que a educação seja empregada como instrumento de libertação, para que o adicionamento do ser se concretize mediante a união das forças até então oprimidas por forças dominantes, criando a consciência da luta fortalecida por meio desse comungar de ideias, que supõe o libertar das amarras do capital.

O processo de escolarização para os índios ainda está configurado em uma dimensão que parece atender a interesses colonialistas: caracterizando a "domesticação" para o trabalho escravo, entre outros, esta concepção infelizmente encontra-se ainda bastante presente nas relações entre o Estado e os povos indígenas, sobretudo nos assuntos ligados à educação escolar. Isto se presta para entender necessidades especiais, uma vez que a educação indígena se configura como especial também. Vidal y Manjón (1999, p. 61) afirmam: “[...] envolve o abandono da dimensão classificatória levando em consideração o potencial de aprendizagem e o desenvolvimento de cada aluno, sendo este seu próprio parâmetro". Tais considerações devem ir além, envolvem também a interatividade e dinamicidade, essas dependendo de dois eixos: o aluno com sua individualidade e evolução e a resposta que a escola deve dar, a partir de sua proposta específica para esse objetivo; e o contexto em que a mesma se efetiva.

Como preconiza a política de educação especial na perspectiva da educação inclusiva, o conceito de necessidades educacionais especiais passa a ser amplamente disseminado a partir da Declaração de Salamanca ${ }^{1}$, ressaltando a interação das características individuais dos alunos com o ambiente social e educacional. A Declaração vem apontar para a organização de sistemas educacionais inclusivos, garantias no acesso de todos os alunos e os apoios necessários para sua participação e aprendizagem. Assim, declara que "[...] as escolas deveriam acomodar todas as crianças independente de suas condições físicas, intelectuais, sociais, emocionais, linguísticas ou outras" (BRASIL, 2008, p. 20).

Nesse sentido, a implementação de uma proposta pedagógica deve considerar as diferenças como princípio para orientação de reestruturação das escolas de ensino regular contemplando, assim, a educação especial. A elaboração de políticas públicas parte, entre os aspectos mais polêmicos, da complexa relação de igualdade-diferença, do envolvimento e do entendimento, na elaboração dessas políticas e de todas as iniciativas, da perspectiva de transformação das escolas, de modo a se ajustarem aos princípios inclusivos de educação.

Tais princípios devem ser pensados para além do necessário em estrutura física para uma escola inclusiva, que supõe ter intrinsecamente o pensar de ir além do "eu", do "nós", objetivando o "todos nós". Carvalho (2016, p. 36) é enfática ao dizer que esta:

Vai além da valorização do ensino ministrado como transmissão de conhecimentos, para a valorização da vida (energia) e da consciência (espírito).

\footnotetext{
1 Declaração de Salamanca (1994): reafirmou o compromisso de uma Educação para Todos, reconhecendo a necessidade e urgência do providenciamento de educação para as crianças, jovens e adultos com necessidades educacionais especiais dentro do sistema regular de ensino; reendossamos a Estrutura de Ação em Educação Especial.
} 
Ela não "prepara" para a vida. Ela é a própria vida que flui devendo possibilitar, do ponto de vista político, ético e estético, o desenvolvimento da sensibilidade e da capacidade crítica e construtiva dos alunos-cidadãos que nela estão, em qualquer etapa do fluxo escolar ou das modalidades de atendimento educacional oferecidas. [...] A ressignificação de seus papéis envolve aspectos políticos, sociais e pedagógicos que vão além das mudanças que se façam na Educação Especial.

$\mathrm{O}$ atendimento a essas necessidades deve envolver o ressignificar de papéis presentes na escola, o direcionar das ações, considerando todos os aspectos, inclusive os políticos, sociais e pedagógicos. Estes, além de constarem do projeto pedagógico (PP) da escola, devem ser exercitados na dinâmica do ensino e aprendizagem. Portanto, o remover barreiras implica efetivar os quatro pilares propostos pela Unesco para a educação no século XXI, que são: um trabalho coletivo de facilitação do aprender a aprender; aprender a fazer; aprender a ser; e aprender a viver junto.

\section{ANÁLISE INTERPRETATIVA DA IDEIA DE DIFERENÇA NOS DISTINTOS CONTEXTOS SOCIAIS}

Pensar a diferença em um contexto social dinâmico é compreender que há situações, pessoas, objetos e cenários que fogem ao padrão uniforme, isto é, que se distinguem dos demais, construindo assim um espaço da diferença, da exclusão e cada vez mais desigual. O termo diferença é originado do latim diferentia, utilizado para definir a diversidade que existe em uma sociedade ou espécie, opondo-se à situação de igualdade ou semelhança.

No Brasil, nas últimas décadas tem-se preconizado a inserção da pessoa com deficiência na escola, no mundo do trabalho e na sociedade de forma geral. Apesar das políticas para sistemas educacionais inclusivos e a inserção da pessoa com deficiência na sociedade contemporânea, a segregação social, cultural e econômica registra a negligência e a fragilidade das nossas políticas sociais e da própria legislação que permite a construção de uma sociedade despreparada para compreender e promover a integração do deficiente, sem concebê-lo enquanto ser dotado de anormalidades, limitado e incapaz.

A conexão dada na história dos homens é que dá origem à história da humanidade. São as relações materiais dos homens que formam a base de todas as suas relações sociais. As regras capitalistas supõem a compreensão de fenômenos sociais a partir de instrumentos que integram esta teoria dialética. Ela trata de todos os aspectos que envolvem a sociedade, tanto na reprodução ideológica, quanto na medida em que se embasa para superação desses ranços.

Evidencia-se a questão da diversidade educacional que coloca o problema das dificuldades escolares no âmbito da crítica de uma cultura homogênea, única e global. Emerge, por trás dessa discussão, uma visão cultural homogênea; na verdade ocorre uma diversidade de manifestações no processo escolar, determinadas por diferenças de classe, raças, culturas, estilos de aprendizagem, comportamentos sociais, emocionais, entre outras. A questão da diferença está atualmente no centro de muitas discussões, principalmente no contexto educacional. Esse termo (referenciado aos diferentes), desde os primórdios, foi tratado de forma particular, no sentido de discriminação, exclusão e classificação de grupos de sujeitos. O reconhecimento de uma sociedade cuja base está assentada no multiculturalismo exige que suas instâncias sejam capazes de identificar a diversidade de seu contexto e dar respostas aos diferentes interesses, desejos e necessidades dos sujeitos.

Os indivíduos são diferentes em suas formas de agir, pensar, interagir; somos diferentes, pensamos, sentimos e reagimos de maneira diferente, e é por isso que vivemos e aprendemos de modo diferente. Nossa dignidade depende substancialmente da diversidade, da alteridade, porque 
precisamos garantir o caráter subjetivo de nossa individualidade. Carvalho (2016, p. 18) ressalta que igualdade "[...] diz respeito aos direitos humanos e não às características das pessoas, como seres que sentem, pensam e apresentam necessidades diferenciadas".

Entende-se, ainda, que a visão clínica com que se trabalha a questão da diferença e, nesse caso, do deficiente, não está distante da visão socioantropológica que sugere o olhar para toda a construção do sujeito e não, especificamente, de forma isolada. Significa olhar a pessoa com deficiência além das características físicas, independentemente de sua origem, classe social, cultural, econômica, pois são as características que constituem as pessoas e, dessa forma, se reafirma a diferença em sentido mais global.

Discutir sobre essa temática é pensar o homem enquanto ser social na busca do reconhecimento da sociedade, como indivíduo que representa um valor, o qual deve ser, nesse sentido, reconhecido pelo "ser humano" e não pelos seus atributos físicos, intelectuais ou suas condições econômicas. Entretanto, esse valor pode se estender a suas potencialidades, quando este demonstra ser capaz de produzir e colaborar com esta mesma sociedade. Sociedade numa perspectiva sociológica representa o resultado histórico das relações entre indivíduos. Durkheim (1978) traz uma visão do papel do homem no mundo com características segregacionistas e elitistas quando afirma:

Não devemos nos dedicar, todos, ao mesmo gênero de vida: temos segundo nossas aptidões, diferentes funções a preencher, e será nisso que nos coloquemos em harmonia com o trabalho que nos incumbe. Nem todos foram feitos para refletir; será preciso que haja sempre homens de sensibilidade e homens de ação (DURKHEIM, 1978, p. 324).

O autor apresenta esta ideia definida pelo viés positivista, em que tal concepção propõe a diferença existente entre os homens por meio das aptidões, excluindo os que não se enquadram a esse modelo de sociedade elitista. Desde sempre o considerado "diferente" foi tratado com desigualdade e desconsideração pela sociedade burguesa, pois este, não tendo competência para servir a esse modelo social, não era e nem é visto como homem ativo, de ação. O que de proveito se tira desse pensamento ora citado é que são os "homens" de sensibilidade que são capazes de refletir sobre a capacidade de todos em aprender, seja no âmbito escolar, seja em outros campos sociais. Segundo Severino (2007, p. 109) a ciência positivista “"...] entende que 'o sujeito' põe o conhecimento a respeito do mundo, mas o faz a partir da experiência que tem da manifestação dos fenômenos, e que o mundo é aquilo que ele se mostra fenomenalmente", sendo a apreensão dos fenômenos feita por meio da experiência controlada.

Na visão de Januzzi (2012, p. 13) o modo de se pensar, de se agir com “o diferente" depende da organização social como um todo, na sua base material, isto é, "[...] na organização para a produção em íntima relação com as descobertas das diversas ciências, das crenças, das ideologias, aprendidas pela complexidade da individualidade humana na sua contribuição física e psíquica”. Para clarificar o contexto da diferença percebido na pessoa considerada diferente, é necessário voltar ao passado, mas não significa dizer que ele explique totalmente o presente, numa intenção de ensinar como deveria ter sido. Apenas mostra-nos o que foi, e que os acontecimentos não se manifestam de forma arbitrária, mas com a existência de relacionamento entre ambos, que sua construção é processo humano, dentro das condições existentes e percebidas como possíveis.

Quando tratamos da diferença no contexto inclusivo, fica subentendido pensar em sua ressignificação dentro de um espaço político como cita Rechico (2008, p. 38): “[...] espaço no qual ela é construída a partir de experiências culturais, comunitárias e práticas sociais, pois dessa forma é entendida e produzida de acordo com a história em que está inserida". 
No percurso da história numa perspectiva "teoricamente" inclusiva, muitas foram as nomeações dadas aos considerados diferentes. Em alguns períodos foram também rotulados, classificados e assim foram distinguindo o "ser" diferente em cada momento da história. Os exemplos dessas nomeações destacam-se como pessoa "retardada", "excepcional", "atrasada", "idiota", "débil", entre outros. Os dispositivos legais fizeram referências a essas pessoas com distintas nomeações como: deficiente, portador de necessidades especiais, pessoas com necessidades especiais, pessoas com necessidades educativas especiais e, atualmente, conforme a Política para Educação Especial numa perspectiva inclusiva (2008), são nomeadas de pessoas com deficiência e / ou mobilidade reduzida. Mudam-se as nomenclaturas, umas mais agressivas, outras menos, no entanto, é visível que o "diferente" é quase sempre subjugado por suas características físicas.

A Política de 2008 repensa o sentido da nomenclatura "necessidades educacionais especiais" quando se refere a esse público "diferente", como pessoa com deficiência, justamente por olhar a diferença que se mostra nas condições para produzir a aprendizagem. Essa Política também considera a pessoa com deficiência aquela que tem impedimentos a longo prazo, de natureza física, mental ou sensorial que, em interação com diversas barreiras, pode ter restringida sua participação plena e efetiva na escola e na sociedade (BRASIL, MEC, 2008).

Deville (2013), interpretando o capital, afirma que é o próprio homem que produz sua história, sendo assim, a "diferença" existe atualmente porque alguém pensou sobre tal fenômeno. Partindo desse pressuposto, a diferença pode ser considerada uma característica da categoria analítica hegemônica, dada a condição de que emerge de um movimento social excludente como a ideologia dominante que o sistema capitalista estabelece.

\section{O PERFIL DOS PROFESSORES QUE ATUAM NO CONTEXTO DA ESCOLA INDÍGENA: DIRETRIZES DE TRABALHO E PROJETO PEDAGÓGICO}

Destaca-se que os principais participantes da pesquisa em questão são os professores que atuam na sala de recurso multifuncional e o coordenador pedagógico da escola indígena, que atende a educação básica nas modalidades educação indígena, educação especial, etapas iniciais e finais do ensino fundamental e ensino médio regular. Estes profissionais serão identificados nesta análise como professor P1 e P2 e o coordenador pedagógico como CP.

Inicia-se tal processo de compreensão destacando as determinações por meio das Diretrizes da Política Nacional de Educação Especial na perspectiva da educação inclusiva vigente, quando esta orienta que a interface da educação especial na educação indígena, do campo e quilombola deve assegurar que recursos, serviços e atendimento educacional especializado estejam presentes nos projetos político-pedagógicos (PP) construídos com base nas diferenças socioculturais desses grupos.

Contudo, o PP 2018 da escola ressalta apenas os benefícios da proposta teóricometodológica, fazendo referência àqueles que a convivência entre os seres humanos propicia, no desenvolvimento de valores que norteiam a vida dos seres humanos em geral. Dá ênfase às inúmeras necessidades, mas não estabelece diretrizes que beneficiem o processo de educação inclusiva. Explicita as implicações sobre o direito do professor e da família (pais) quando afirma: "Inclusão implica por um lado o direito de o professor receber apoio e oportunidades para seu desenvolvimento profissional e, por outro, o direito dos pais de esperar que seus filhos recebam educação adequada". Apresenta-se confuso o entendimento sobre a educação inclusiva e o serviço de AEE. Sendo este um serviço advindo de políticas públicas, um dos instrumentos que deve 
mediar a educação inclusiva na escola, precisa definir-se claramente como funciona nesse espaço e quais seus objetivos para com o público da escola.

Reafirma-se que a história da educação escolar indígena é uma história de lutas, conquistas e resistência. A resistência à inclusão de alunos indígenas tem sido superada, de forma paulatina, pois o processo inclusivo, ainda deficiente, já se iniciou, mas necessita de muitos alinhamentos e comprometimentos dos envolvidos no processo de aprendizagem: alunos, famílias, comunidade escolar. Este processo deve ser contínuo, privilegiando a diversidade e suas peculiaridades em consonância com as normativas vigentes.

No PP 2018 (p. 22) da escola está evidenciado que “[...] todo conhecimento é construído social e coletivamente", que as crianças com deficiências devem estar inseridas no meio social, a começar pela escola. Aqui se constata o ideal de consciência sobre o "direito" e a "intenção" no ato de educar, no fazer pedagógico comprometido com todos os educandos, ao destacar sobre a ação pedagógica:

A ação pedagógica conduz o convívio para a vida em sociedade, produzindo cultura e usufruindo-se dela. É certo que as modificações em todos os âmbitos da sociedade afloram as desigualdades, de modo a impulsionar discussões sobre as exclusões e evidenciando-se a necessidade de mudanças nas políticas públicas. Enfim, uma parcela da população com deficiência não precisa de grandes alterações do contexto, mas devemos considerar a diversidade de cada caso (PP, 2018, p. 22).

O documento explicita que a ação pedagógica é ferramenta importante na produção de cultura e facilita o convívio em sociedade. No tratar das adequações para atender a diversidade da população com deficiência, o documento enfatiza não precisar de alterações no contexto, acreditando-se referir-se ao contexto escolar. À luz das contradições, afirmar que "a população com deficiência não precisa de adequações", talvez se refira ao fato de que não cabe evidenciar a diferença, por serem todos iguais perante a lei, portanto, com os mesmos direitos. Não leva em conta, porém, como são substancialmente importantes as adequações no âmbito pedagógico, desde o aspecto arquitetônico até as atividades didático-pedagógicas, tendo em vista que o educando com deficiência depende de outros mecanismos que deem suporte a seu processo de aprendizagem.

O perfil dos professores que atuam na educação especial na escola indígena também deveria estar registrado no PP e no projeto de implantação da sala de recurso multifuncional (SRM); entretanto, não existe qualquer alusão a isto, assim como às diretrizes de todo o trabalho desenvolvido pela escola. Percebe-se que as professoras responsáveis pela SRM da escola não dispõem de conhecimento aprofundado sobre o AEE; sobre sua organização e funcionamento; e seu real significado no espaço escolar, pois as dificuldades evidenciadas no projeto elaborado indicam necessidade de ajuda, desde a implantação da sala de recurso até a execução das atividades que favoreçam o processo inclusivo do público da escola. Constata-se, também, que o Projeto Pedagógico da escola não inclui em sua demanda o serviço de Atendimento Educacional Especializado, com base nos dispositivos da PNEEPEI (2008, p. 27) que trata como AEE:

O conjunto de atividades, recursos de acessibilidade e pedagógicos organizados institucionalmente, prestado de forma complementar e suplementar à formação dos alunos no ensino regular. $\mathrm{O}$ atendimento educacional especializado deve integrar a proposta pedagógica da escola, envolver a participação da família e ser realizado em articulação com as demais políticas públicas.

Por esses elementos, verifica-se que a intencionalidade de existência desse serviço transparece com a implantação da SRM na escola, entretanto, a consciência do significado deste trabalho ainda é subjetiva. Assim como o AEE, a SRM — o local onde o atendimento acontece e 
a sala funciona — não são mencionados no projeto pedagógico, e isto implica dizer que também seus significados não são objeto de conhecimento para os que atuam no espaço daquela escola. Como especifica o parágrafo $1^{\circ}$ da PNEEPEI (2008, p. 28), “As salas de recursos multifuncionais são ambientes dotados de equipamentos, mobiliários e materiais didáticos e pedagógicos para a oferta do atendimento educacional especializado". Nesse espaço articula-se todo o trabalho de inclusão na escola, seja no envolvimento de alunos em relação ao pedagógico, seja no envolvimento de profissionais da escola, colocando em destaque os professores de sala de aula comum.

Nesse sentido, analisam-se alguns pontos concernentes ao trabalho de educação inclusiva realizado pela equipe pedagógica da escola. Ao ser questionado sobre seu entendimento quanto à educação especial e à educação inclusiva, o coordenador pedagógico (CP, 2018) respondeu:

Educação especial é uma modalidade de educação que vem atender alunos com algumas deficiências, com suas necessidades especiais. Enquanto, que a educação inclusiva se refere ao atendimento desses alunos junto aos outros tidos como normais. Inclusão é eles interagirem na mesma classe.

O profissional que desenvolve o trabalho na coordenação pedagógica possui formação em licenciatura intercultural com habilitação em ciências sociais, com 38 anos de tempo de serviço na área da educação, já atuando nessa função há alguns anos. Apresenta dificuldades para fazer a distinção entre educação inclusiva e educação especial. Emite compreensão superficial, a de que educação inclusiva se relaciona apenas à questão de interação social escolar e também não deixa claro que a modalidade de educação especial se refere ao atendimento desse público e à articulação dela no ambiente escolar, sob forma de proposição de formação continuada aos professores e aos demais profissionais da escola. Como afirma a Resolução CEE/RR n. 7 set. 2009, no Art. 30, "A Educação Especial integra o Sistema Estadual de Educação de Roraima identificando-se com sua finalidade que é a de formar cidadãos conscientes e participativos através da promoção do seu desenvolvimento".

Entretanto, observa-se que a formação de cidadãos conscientes e participativos não está sendo consolidada aos profissionais que trabalham nesse contexto escolar e, consequentemente, não atenderá a perspectiva proposta, promovendo seu desenvolvimento. Com isso, ressalta-se a falta de capacitação e qualificação do corpo docente para atender as necessidades educacionais especiais do alunado, como especifica o inciso IV do Art. $5^{\circ}$ da referida Resolução.

Quando se menciona um trabalho articulado entre coordenação pedagógica, SEM e professores da sala de aula regular, o profissional CP afirma existir muita dificuldade. Diz que, por mais que se queira atender tal demanda, não dispõe de formação específica, apenas de algumas leituras, que não lhe dão o suporte necessário para auxiliar o trabalho pedagógico, assim como acontece com a maioria dos professores da escola. Afirma, também, ser esta uma deficiência do próprio sistema que, às vezes, ignora esse campo de trabalho. Mas ressalta que tem procurado fazer a união entre esses setores da escola, seja no ouvir os professores da SRM para fazer o "ajustamento do material"; a adaptação dos conteúdos à realidade dos alunos; mas que não obtém respostas à altura das expectativas, embora estejam "[...] procurando fazer o máximo que podemos" (CP, 2018).

Sabe-se que nesse campo de trabalho apresentam-se inúmeras dificuldades, o CP destaca entre estas a questão estrutural, "recursos humanos" que subsidiem esse processo. E segue: "[...] alguns professores têm se sensibilizado com a situação de alguns alunos, como alunos com baixa visão... procuram ampliar a fonte para que desenvolvam suas atividades com mais facilidade (CP, 2018). Insiste que até os professores com formação específica apresentam dificuldades para trabalhar com a língua portuguesa, língua espanhola e também com a língua materna dos indígenas. 
Explica, ainda, que a falta de formação continuada é um dos entraves nesse processo, pois precisaria alcançar todos os professores, até mesmo aqueles que não estão em sala de aula. Acredita que o acesso ao conhecimento sobre educação especial "[...] favoreceria a sensibilização desses profissionais, pois quando se tem conhecimento, sabe-se por onde caminhar".

O CP entende por escola inclusiva aquela que recebe alunos não indígenas, alunos com deficiências, toda a diversidade; aquela que respeita toda a diversidade existente. E resume "[...] inclusão na escola é você respeitar essa diversidade". Ao pautar-se um discurso sobre diversidade, faz-se viável entender que, além das diferenças sociais e econômicas, grande parte dos alunos tem origem nas desigualdades, indicando diferenças culturais atreladas a diferenças étnicas ou de grupos sociais tais como indígenas, imigrantes, entre outros. À vista disso, a ideia de diversidade é marcada por uma determinada concepção a respeito das relações entre desigualdade e diferenças culturais. Nessa lógica, recorre-se a Canen (2001, p. 207) que afirma:

Reconhecer que a sociedade brasileira é multicultural significa compreender a diversidade étnica e cultural dos diferentes grupos sociais que a compõem. Entretanto, significa também constatar as desigualdades no acesso a bens econômicos e culturais por parte dos diferentes grupos, em que determinantes de classe social, raça, gênero e diversidade cultural atuam de forma marcante.

A compreensão sobre diversidade deve ultrapassar a ideia de reconhecimento dos modos de vida dos grupos minoritários ou dissidentes. Dessa forma, tende a produzir o pluralismo cultural que fragmenta a própria ideia de cultura. A partir do reconhecimento identitário cultural que perpassa a diversidade cultural de determinados grupos, e a diferenciação destes quando uns são valorizados em detrimento de outros, é que se pluraliza o conceito de cultura, ainda que não seja fácil manter seu caráter positivo.

Nesse caminhar, a escola inclusiva subentende ultrapassar ideias contraditórias de diversidade, cultura, entre outras, buscando superar fronteiras que a impedem de produzir a cultura necessária para a emancipação de todos. Nesse sentido, se voltam às reflexões do CP quando afirma ter "[...] procurado fazer um trabalho que favoreça os alunos por meio do plano de ensino, incluindo essa diversidade, propiciando atividades que valorizem a questão cultural".

Embora esse profissional afirme que promove a acessibilidade no âmbito pedagógico, não compreende que o serviço de AEE viabiliza a educação inclusiva, pois não sabe exatamente o que esta significa, e qual o seu papel no espaço escolar. Explicita, apenas, que o AEE “[...] é para atender o aluno com deficiência em sua necessidade específica". Ressalta que os professores da SRM não têm formação específica para atuarem na educação especial, e que, ainda assim, tentam desenvolver um trabalho com os professores de sala de aula regular. Afirma que os orienta quanto ao processo de inclusão, embora não desenvolvam um trabalho de formação continuada na escola, e que somente participam das formações promovidas pela Divisão de Educação Especial (DIEE).

No que diz respeito ao acompanhamento do trabalho do professor que recebe em sala de aula um aluno com deficiência, não existe orientação específica, por falta de conhecimento sobre essa área. O CP expõe que, em algumas salas de aula, existe um professor auxiliar para dar suporte ao trabalho do titular, porém, não há cuidador para os alunos que necessitam.

Como se afirmou inicialmente, para entender o processo de educação inclusiva mediada pela educação especial, é fundamental que se compreenda este universo a partir do entendimento sobre o que significa deficiência. Para tanto, recorremos à definição de Skliar (2003, p. 56) que é enfático ao afirmar que:

[...] a presunção de que a deficiência é, simplesmente um fato biológico e que apresenta características universais deveria ser, mais uma vez, problematizada epistemologicamente: compreender o discurso da deficiência, para logo depois 
revelar que o objeto desse discurso não é a pessoa que está em uma cadeira de rodas ou aquela que usa uma prótese auditiva, ou aquela que não aprende segundo o ritmo e a forma como a norma espera, senão os processos históricos, culturais, sociais e econômicos que regulam e controlam a maneira pela qual são pensados e inventados os corpos, as mentes, a linguagem, a sexualidade dos outros.

Segundo o autor, são os processos históricos, culturais, sociais e econômicos que tendem a regular os indivíduos, a sua maneira de pensar seus corpos, mentes e demais características, seu modo de viver. Portanto, a formação pensada deve vincular-se ao processo de compreensão global do indivíduo. Tarefa a ser desempenhada pelo sistema estadual de educação de Roraima, em subsídio ao conhecimento desses profissionais, em observância ao Art. $5^{\circ}$ da Resolução CEE RR de 2009 (p. 3), que em três incisos assim explicita o processo de formação de profissionais da educação:

[...] IV - Capacitar e qualificar o corpo docente para atender às necessidades educacionais especiais do alunado;

V - Promover oportunidades de formação e capacitação de profissionais para atuarem na Educação Especial e na Educação Inclusiva;

VI - Prover recursos didáticos, tecnologia assistiva e comunicação, inclusive com instalação de salas de recursos e centros de atendimento educacional especializado.

A efetivação desse serviço reduziria as dificuldades apresentadas pelos profissionais e os conduziria a uma atuação mais eficaz no processo de inclusão dos estudantes no espaço escolar; mais especificamente promoveria aprendizagem no real sentido de emancipação humana.

Ao dialogar com as professoras participantes da pesquisa, P1 e P2, é que se entende o campo de trabalho em que atuam. Informam que atendem, hoje, na SRM da escola, um total de 15 alunos da educação especial. Destacam os motivos que as levaram a trabalhar na educação especial.

A P1 deixa claro que não sabia nada dessa área, mas foi buscando por meio de pesquisa na internet. Há quatro anos atua na educação especial, explica que antes dela os professores que trabalharam na SRM eram da cidade de Boa Vista e não se demoravam na comunidade desenvolvendo tal trabalho. É enfática ao dizer que gosta do que faz, que se sente na obrigação de ajudar, pois os alunos precisam muito.

A professora demonstra afinidade e compromisso com a tarefa de ensinar, ainda que seu entendimento e distinção do que seria educação especial e educação inclusiva seja singular: "Todos somos especiais independente da inclusão, mas a inclusão requer uma atenção aprofundada, pois independe de cor, raça, religião, todos são especiais. A educação especial faz parte do processo de inclusão" (P1).

Quanto à compreensão sobre o desenvolvimento do AEE, explica que sua função é ajudar, ainda que sem recursos adequados; é tentar produzir material acessível para os alunos, facilitando o ensino na sala regular, em que faz intermediação, o que não é nada fácil na escola. Dizem que muitas vezes são incompreendidas, pois não existe interação entre coordenação pedagógica, professor de sala regular e professor da SEM: não existe apoio ao trabalho do AEE. Se querem que o trabalho aconteça, buscam conhecimentos sozinhas, estudam sozinhas, ela e sua colega do AEE. E diz ainda: "[...] a coordenação pedagógica não conhece, não faz ideia desse campo de trabalho, pedimos ajuda constantemente, mas jogam toda a responsabilidade para nós do AEE". E conclui que a coordenação pedagógica não acompanha o trabalho que elas desenvolvem, ficando a responsabilidade somente sobre elas. 
No que se refere ao ganho pessoal no realizar da atividade profissional, ressalta que ganhou bastante experiência, já atua há 23 anos na educação; diz ser gratificante ajudar os alunos, ajudar o próximo, porém, se entristece com a carência de recursos, por exemplo: material pedagógico acessível: “[...] se quisermos trabalhar temos que tirar do bolso". Além da falta de recursos, cita também as principais dificuldades enfrentadas para desenvolver estratégias de inclusão na escola, como a falta do envolvimento de todos, de um planejamento adequado, tanto o anual - que precisa incluir a demanda da educação especial — quanto o plano de aula diário.

A clientela está aumentando cada dia mais, estão nascendo muitos alunos com deficiência e a escola precisa atentar para essa realidade, justamente por isso que nossa escola não pode ser considerada inclusiva. Não atende a contento a demanda existente. (P1, 2018)

A professora P1 relata que desde 2009, até agora, se observa que a escola caminha paulatinamente para uma perspectiva inclusiva:

E se não tivermos uma equipe empenhada com esse processo, vai continuar em ritmo lento. Tudo foi iniciado por nós, estamos tentando cumprir com nossas obrigações e com certeza está sendo proveitoso. Os alunos não faltam ao AEE, vimos que o processo inclusivo na educação especial é bastante lento, mas está acontecendo. (P1, 2018)

A colaboração entre os profissionais envolvidos no processo aponta conquistas importantes na inclusão escolar, ao mesmo tempo em que colabora para a formação continuada de professores. Esta colaboração deve ser entendida como estratégia de trabalho pedagógico, ou seja, a contribuição de todos os agentes educacionais, um trabalho em equipe, exigindo ajuda mútua. Esta colaboração também é definida por Friend \& Cook (1990) como um estilo de interação entre, no mínimo, dois parceiros equivalentes, engajados num processo conjunto de tomada de decisão, trabalhando em direção a um objetivo comum.

Nesse sentido, é possível entender que a educação inclusiva acontece objetivamente quando todos os parceiros educacionais se envolvem e fazem a "diferença", agindo nos moldes que convergem para a inclusão, cujo diferencial está na parceria entre professores responsáveis por promover o aprendizado desse público, assim como de todos os alunos da escola.

A professora identificada como P2 tem 15 anos de atuação na área da educação, ainda cursando o ensino superior em comunicação e artes, com apenas um ano e cinco meses trabalhando na SRM, sem experiência e conhecimento na área. Ela explica como foi iniciar o trabalho na educação especial. Relata:

Quando iniciei não tinha nenhuma experiência nesse campo, mas com o apoio da colega, me ensinando, ajudando, venho melhorando minha prática. Estou com apenas um ano e alguns meses desenvolvendo um trabalho na educação especial. (P2, 2018)

A falta de experiência da professora transparece, uma vez que não compreende do que se trata esse campo de trabalho amplamente. P2 responde à sua maneira algumas questões como: o que é inclusão, educação especial, não conseguindo traçar conceitos científicos. Refere-se à inclusão como: "[...] é pra incluir os alunos especiais aqui na escola". Em sua concepção, a inclusão é restrita aos alunos "especiais", enquanto educação especial seria "[...] atendimento aos alunos que têm algum tipo de deficiência". Assim também teceu suas considerações sobre o AEE e sua função. AEE faz "[...] atendimento aos alunos com deficiência, auxiliando-os na sala de aula regular". Sobre sua função, diz que "[...] é pegar os planos dos professores titulares e adaptar, pesquisar outros 
materiais para auxiliar os alunos em suas necessidades, sempre facilitar a inclusão desse público no espaço escolar" (P2).

A professora P2 menciona o trabalho de adaptação curricular sem saber teoricamente o que está desenvolvendo como atividade inclusiva. A carência de formação consistente implica um desajuste entre o teórico e o prático, significativamente no processo de ensino e aprendizagem. Ter o conhecimento não basta, é preciso compreendê-lo como apresenta Nóvoa (2001, p. 2), ao nos permitir refletir: "[...] não basta deter o conhecimento para o saber transmitir a alguém, é preciso compreender o conhecimento, ser capaz de o reorganizar, ser capaz de o reelaborar e de transpôlo em situação didática em sua sala de aula". No caso específico do trabalho com o AEE, significa o atendimento e auxílio na sala de aula regular.

É com a intenção de valorizar todas as ações no âmbito educacional, e por que não dizer dos professores aqui mencionados que, mesmo diante das dificuldades demonstram preocupação com o processo inclusivo dos alunos envolvidos na educação especial, que se utiliza aqui o pensamento de Edgar Morin (2011, p. 13) que, com sua obra Os sete saberes necessários à educação do futuro explica o que realmente se faz importante nesse contexto educacional.

É importante ter o pensamento complexo, ecologizado, capaz de relacionar, contextualizar e religar diferentes saberes ou dimensões da vida. A humanidade precisa de mentes mais abertas, escutas mais sensíveis, pessoas responsáveis e comprometidas com a transformação de si e do outro.

O autor permite reflexões no sentido de que os saberes ultrapassam os científicos, indo além e valorizando outros tipos de saberes, indispensáveis na construção de novos saberes e, porque não dizer, na valorização da vida, quando se age na transformação de si e do outro. No entanto, a construção de outros saberes se faz também pela via coletiva, pela parceria, pela interação, algo ainda ausente na escola onde a referida professora trabalha. Esta indica que, na maioria das vezes, professoras trabalham isoladas e que, nas oportunidades que surgem como em encontros pedagógicos, estão sempre ressaltando a importância de trabalhos em parceria, que sejam feitos em consonância com o que se executa em sala de aula. Prossegue afirmando que a iniciativa de um trabalho parceiro é sempre delas, professoras do AEE, não há importância dada pelos demais, como a coordenação pedagógica, nem de professores de sala regular.

Sobre os impactos desse trabalho em sua vida pessoal, quanto ao que trouxe de relevante, destaca pontos importantes como: "[...] a paciência, o cuidado com o que falo, a forma que procuramos ajudar os alunos, transmitindo esse cuidado aos meus filhos, principalmente com a minha filha com deficiência intelectual" (P2).

O envolvimento desses profissionais com seus alunos parece gerar uma reflexão mais profunda quanto à necessidade de cuidar dos "seus", deixando-os mais sensíveis à realidade do outro, o que fica explicitado nas várias histórias de profissionais que disseram se afinar com o campo da educação especial por terem alguém na família com deficiência, ou alguém que precisa de outros cuidados. A P2 também faz referências às dificuldades apresentadas nesse campo de atuação, quando reafirma a falta de trabalho coletivo, a má vontade de professores em realizar trabalhos voltados ao auxílio do público da educação especial. Diz que nem a própria coordenação pedagógica se mobiliza para promover formação continuada na escola. E ratifica que todo o trabalho desenvolvido parte da iniciativa das professoras da sala de recurso multifuncional. $\mathrm{Na}$ verdade, os outros profissionais mantêm-se resistentes.

Alguns professores auxiliares da escola demonstram entender o caminho para a educação inclusiva, no entanto, não se colocam à disposição para facilitar a acessibilidade pedagógica, talvez, por não quererem tomar a responsabilidade no que se refere a ensiná-los. A grande maioria não se sensibiliza com a inclusão escolar. P2 ainda conclui: "O processo de inclusão é complexo, e isso é 
uma realidade da grande maioria das escolas indígenas. Em quase todas, as dificuldades são semelhantes ou se apresentam em situações piores".

Ao falar de satisfação quando o contexto não favorece práticas de qualidade, isto é, processos de inclusão na escola indígena, o que também não é favorecido pela atuação de professores no auxílio a alunos com deficiência, podem-se relembrar concepções de Tardif (2007, p. 223): “[...] o saber é um construto social produzido pela racionalidade concreta dos atores, por suas deliberações, racionalizações e motivações que constituem a fonte de seus julgamentos, escolhas e decisões". Saberes não são só os produzidos na universidade, mas também os mobilizados e utilizados nas práticas de ensino de professores, em todas as suas tarefas.

Professores retratam a experiência vivenciada em um campo de trabalho pouco conhecido, mas que permite um mobilizar constante desses professores em busca de conhecimento e aperfeiçoamento de suas práticas. Pimenta (2002) afirma que alunos professores já dispõem de saberes sobre o que é ser professor: seja de sua experiência como alunos; seja de algum professor que trouxe significado a sua vida escolar; seja de mudanças históricas da profissão ou mesmo do exercício da docência em diferentes escolas; seja da vivência de falta de valorização social e financeira.

\section{O ATENDIMENTO EDUCACIONAL ESPECIALIZADO COMO PROCESSO DE INCLUSÃO: ESCOLA E ALUNOS INDÍGENAS}

Para compreender o processo inclusivo no espaço escolar é importante conhecer o principal objetivo do Atendimento Educacional Especializado, complementar e / ou suplementar à formação dos alunos com vista à autonomia e independência na escola e fora dela. Pautando-se no Decreto n. 7.611/2011, que define o AEE como um conjunto de atividades, recursos de acessibilidade e pedagógicos organizados institucional e continuamente, espera-se que seja prestado da seguinte forma:

I - Complementar à formação dos estudantes com deficiência, transtomos globais do desenvolvimento, como apoio permanente e limitado no tempo e na frequência dos estudantes às salas de recursos multifuncionais; ou

II - Suplementar à formação de estudantes com altas habilidades ou superdotação.

Conforme o Decreto mencionado, o AEE tem como objetivos:

I - Prover condições de acesso, participação e aprendizagem no ensino regular e garantir serviços de apoio especializados de acordo com as necessidades individuais dos estudantes;

II - Garantir a transversalidade das ações da educação especial no ensino regular; III - Fomentar o desenvolvimento de recursos didáticos e pedagógicos que eliminem as barreiras no processo de ensino e aprendizagem; e

IV - Assegurar condições para a continuidade de estudos nos demais níveis, etapas e modalidade de ensino.

O serviço deve ser acompanhado por instrumentos que possibilitem monitoramento e avaliação da oferta realizada nas escolas da rede pública e nos centros de atendimento educacional especializado, públicos ou conveniados. Desse modo, observa-se que a efetivação desse serviço ultrapassa os muros da escola, pois as parcerias intersetoriais são fundamentais no processo inclusivo que requer atitudes humanitárias desencadeadoras de uma educação emancipadora. Para isto, é viável uma prática e uma formação pedagógica baseadas numa concepção humanizadora e emancipadora cuja orientação evite correr o risco de não alcançar os objetivos propostos pela 
educação escolar. Portanto, a formação de professores é tanto inicial como continuada, de modo que enseje realizar ações pedagógicas humanizadoras, atuando não apenas no ensinar, mas valorizando a pessoa humana para além de suas necessidades pedagógicas.

A professora P1 ressalta que o processo de formação continuada ofertado pela DIEE é difícil, pois os saberes disponibilizados para professores indígenas são os mesmos das demais escolas, ou seja, de escolas não indígenas, não existindo "respeito" à cultura indígena específica. Exemplificando: não existe adaptação que favoreça o elemento cultural, a língua materna, nos contextos Macuxi e Wapichana; as adaptações são feitas na própria comunidade, em cartazes, atividades diversas etc.

P1 também questiona a formação limitada dispensada pela Divisão e por outras instituições, no entanto, sabe-se que o domínio dessas línguas é restrito a seus pares, não dispondo o órgão público de profissionais especializados nessas áreas, ainda que a interação entre estes seja defendida pela chefe da DIEE, que promove troca de saberes culturais que dão base para o alavancar da educação inclusiva nos espaços escolares.

A professora P1 também demonstra insatisfação quanto ao serviço de AEE realizado nas escolas indígenas, ressaltando-o como limitado, e dizendo que nem tudo é o que parece, nomeando-o muitas vezes como "camuflado". As escolas que dispõem desse serviço dizem que têm sala de recurso multifuncional, o que às vezes consta apenas no papel, pois a SRM de fato não existe. $\mathrm{E}$ as que a têm, não desfrutam de estrutura para o desenvolvimento do trabalho adequado.

O AEE é um serviço que recomenda o envolvimento de todos, principalmente da família. O que se observa é que a importância dada a este é mínima, carecendo de mais atenção desde o sistema de ensino mais amplo até a equipe gestora da escola, pelo fato de se tratar de "[...] uma tarefa difícil, complexa" (P2). A educação especial referenciada na PNEEPEI (2008, p. 20) direciona suas ações para o atendimento às especificidades dos alunos no processo educacional e, "[...] no âmbito de uma atuação mais ampla na escola, orienta a organização de redes de apoio, a formação continuada, a identificação de recursos, serviços e desenvolvimento de práticas colaborativas".

Seguindo a lógica de práticas colaborativas, cabe precisar o termo parceria, que sustenta essas práticas. Significa, segundo o dicionário Aurélio: reunião de pessoas que visam um interesse em comum; sociedade. Assim, entende-se que todos sabem o objetivo comum da atuação em conjunto. Entre as formas de trabalho em conjunto, o ensino colaborativo tem sido utilizado para favorecer a inclusão escolar, envolvendo a parceria direta entre professores da educação "comum" e especial.

O ensino colaborativo pode efetivar-se de várias maneiras:

Um professor como suporte - O professor da Educação Comum e o educador especial atuam juntos em sala de aula, mas um professor apresenta as instruções, enquanto o outro providencia o apoio aos estudantes. Pode ser feito o rodízio trocando os papéis.

Estações de ensino - Como se fossem "os cantinhos da atividade" significa que a sala será dividida em grupos que passarão pelas diversas partes da atividade, sendo que em cada uma delas os professores se dividirão para explicar aos alunos o que deverá ser feito. Então, os grupos se alternam de local e os professores repetem as informações para novos grupos de alunos.

Ensino paralelo - A instrução é planejada de forma articulada, mas cada professor fica com $50 \%$ do grupo de alunos.

Ensino alternativo - Um professor apresenta instruções para um grande grupo de alunos, enquanto o outro interage com um pequeno grupo de alunos. 
Equipe de ensino - Ensino cooperativo (ensino interativo). Cada professor dá igualmente suas instruções. Ex.: O professor passa instruções de Matemática e o co-professor ilustra com os exemplos (CAPELLINI, 2008, p. 9)

Pensar em educação inclusiva na escola indígena significa seguir tais orientações, entretanto a realidade imposta sugere o continuar da luta para sua efetivação. A escola, mesmo sendo indígena, conforme relato do coordenador pedagógico, não recebe só alunos indígenas e, por isso, a atenção deve ser redobrada. O cuidado no planejamento é indispensável em todas as ações pedagógicas.

Ao observar todos os entraves no processo de educação inclusiva na escola indígena, os quais refletem no principal objetivo o processo de ensino e aprendizagem desse público, delineiase que a falta de conhecimento do professor indígena, tanto do que trabalha em sala de aula regular, quanto o que desenvolve o AEE, se refere à questão do conhecimento sobre o desenvolvimento dos alunos em vários aspectos, dentre esses: aspectos biológicos; entendimento sobre zona de desenvolvimento real e zona de desenvolvimento proximal; e outros necessários que influenciam o desenvolvimento humano nos aspectos cognitivos. A psicologia histórico-cultural defendida por Vygotsky vem trazer algumas explicações pautadas em aportes científicos, como forma de superação de paradigmas que historicamente necessitam ser superados.

Como retrata a história, Vygotsky (em obra publicada só em 1988) demonstrou os estudos em que buscou desenvolver um método que permitisse a compreensão da natureza do comportamento humano, enquanto parte do desenvolvimento histórico geral de nossa espécie. Terminou por sistematizar uma abordagem fundamentalmente nova sobre o processo de desenvolvimento do pensamento e das funções cognitivas complexas de um sujeito contextualizado e, portanto, histórico. Nesse novo método a essência é o princípio de que todos os fenômenos têm uma história configurada por mudanças qualitativas e quantitativas que, contudo, devem ser analisados como processos em movimento e mudança.

É a partir dessa concepção que se deve pautar a formação do professor, pois os processos histórico-sociais influenciam o desenvolvimento do pensamento, portanto, as funções cognitivas. Isto se dá via movimento histórico, que consiste numa dinâmica de transformações, dependendo das influências sofridas por meio de mediações, possibilitadas tanto nas esferas escolares (que trabalham na intenção de favorecer o acesso ao capital cultural científico) quanto na esfera social, em que as interações acontecem de diferentes maneiras.

Assim como Vygotsky, acredita-se que esse professorado precisa compreender o ser humano, e que isso depende do estudo do processo de internalização de formas culturalmente dadas de funcionamento psicológico, a partir da premissa com a qual Vygotsky tentou explicar a transformação dos processos psicológicos elementares, relacionados a fatores biológicos do desenvolvimento, nos chamados processos superiores — resultantes da inserção do homem em determinado contexto sócio-histórico.

Conforme a filosofia marxista, o homem é concebido como sujeito ativo que cria o meio, a realidade, ou seja, age na natureza e como produto desse meio (a natureza age sobre os homens). Nesse contexto dialético, o sujeito do conhecimento não se comporta contemplativamente diante da realidade, mas age sobre ela. E age principalmente se constantemente for estimulado pelo mundo externo. Para melhor explicar, utiliza-se o pensamento de Rego (2014, p. 101):

E como consequência desse estímulo internaliza (de modo ativo), o conhecimento (conceitos, valores, significados) construído pelos homens ao longo da história. Vygotsky parte do princípio e postula que é na atividade prática, nas interações estabelecidas entre homens e a natureza que as funções psíquicas, especificamente humanas, nascem e se desenvolvem. Detém-se na investigação 
do surgimento de novas estruturas cognitivas a partir da demanda social, da necessidade de novos instrumentos de trabalho e pensamento.

Nesse sentido, os estímulos externos precisam fazer parte da vida profissional dos professores, para que se tornem sujeitos ativos que agem sobre a realidade de seus alunos, proporcionado novas estruturas cognitivas por meio de novos instrumentos de trabalho e pensamento. Vygotsky defende que a mediação de todo processo acontece por meio da linguagem, já que esta é considerada o sistema simbólico principal de todos os grupos humanos, a qual intervém entre sujeito e objeto de conhecimento. Entende que este processo de mediação homemmundo acontece via trabalho e o uso de signos — símbolos. E que a relação do sujeito com o ambiente é mediada, pois sendo este sujeito do conhecimento, não tem acesso direto aos objetos e, sim, a sistemas simbólicos que representam a realidade.

A relação homem-mundo se dá, primeiro, via representação simbólica, só depois há o acesso aos objetos, o que significa ser a própria realidade, a qual pode ser transformada por ele, dando significados positivos ou negativos. A escola pensada numa perspectiva inclusiva é aquela que atende a todos nos diversos aspectos, entretanto, deve atender fundamentalmente no processo de aprendizagem. Ao recorrer à visão de Vygotsky sobre a escola numa perspectiva histórica, afirma-se que se o faz por oferecer conteúdo e desenvolver modalidades de pensamento bastante específicas, com papel diferente e insubstituível, na apropriação pelo sujeito da experiência culturalmente acumulada. Juntamente com isso, a escola representa "[...] o elemento imprescindível para a realização plena do desenvolvimento dos indivíduos (que vivem em sociedades escolarizadas) já que promove um modo mais sofisticado de analisar e generalizar os elementos da realidade: o pensamento conceitual" (REGO, 2014, p. 104).

Vista como um elemento insubstituível, a escola representa um espaço que visa oferecer a oportunidade de desenvolvimento dos sujeitos, por meio da experiência da cultura ofertada e acumulada. Um espaço que deve possibilitar igualdade de condições a todos os sujeitos que dela participam, inclusive aos indivíduos com deficiência, os quais têm impedimentos de longo prazo, de natureza física, mental ou sensorial que, em interação com diversas barreiras, podem ter restringida sua participação plena e efetiva na escola e na sociedade.

Para atender esse público, a escola enfrenta desafios como a falta de preparação dos agentes educacionais para responder a suas necessidades, principalmente com relação à capacitação técnica de professores, mas essencialmente para realizar um trabalho sério que se situa para além das alterações didáticas e metodológicas, para que abrace a dimensão humana, política e ética por parte dos sujeitos envolvidos (HARGREAVES, 2002).

\section{CONSIDERAÇÕES}

As análises realizadas sobre o perfil dos professores do AEE que atuam na escola indígena e o processo de inclusão de alunos por meio do Atendimento Educacional Especializado demonstram que há deficiência no processo dispensado de formação continuada, bem como de assistência por parte do poder público na esfera estadual.

Sabe-se que os elementos que constituem a identidade do profissional que atua na educação especial partem da esfera pessoal, da experiência profissional e também da formação acadêmica. Embora se tenha dado ênfase ao relato de professores, do coordenador pedagógico, bem como à forma como é desenvolvida a formação continuada desses profissionais, contempla-se um caráter de denúncia em relação à situação da educação especial presente na escola indígena.

O quadro deficitário de apoio à inclusão no ambiente escolar indígena perdura ainda hoje, uma vez que as dificuldades apresentadas dependem da sensibilização de todos os envolvidos no 
processo educacional, mas, principalmente, dos agentes públicos responsáveis por fazer valer o direito a uma educação de qualidade.

Apesar da disponibilização de fundamentos específicos desse campo na formação continuada, estes parecem não ter gerado efeitos na prática docente com alunos que apresentam deficiências específicas. Isto se verificou no discurso das professoras P1 e P2 quando afirmam não estarem preparadas para atuarem no atendimento a determinados alunos, e que vão tentando desenvolver um trabalho que os auxilie, para que não fiquem prejudicados, sem nenhuma assistência.

Considera-se precoce afirmar que as estruturas fundantes que constituem essa identidade profissional para a realidade da escola indígena, nesse contexto recente, são definitivas. $\mathrm{Na}$ realidade pensada, o processo inclusivo por meio da educação especial faz com que essa identidade configure-se, também, princípio formativo, devendo os elementos substanciais serem analisados prioritariamente a partir da cultura de cada docente indígena, para que este profissional incentive e valorize a cultura do discente no lugar de existência, ou seja, de sua própria comunidade indígena.

As nossas diferenças são a nossa força enquanto espécie e enquanto comunidade mundial. (MANDELA, 2002)

\section{REFERÊNCIAS}

BARRETO, Maíra de Paula. O infanticídio indígena no Brasil sob a perspectiva do controle da convencionalidade: enfoque dos direitos humanos. Salamanca, Espanha: Ediciones Universidad de Salamanca, 2016.

BRASIL. Constituição da República Federativa do Brasil. Promulgada em 5 de outubro de 1988. São Paulo: Saraiva, 2005.

BRASIL. Ministério da Educação e do Desporto. Secretaria de Educação Fundamental. Política Nacional de Educaşão Básica. Brasília, Distrito Federal: MEC / SEF / DPEF, 1994.

BRASIL. Educar na diversidade: material de formação docente. 3. ed. Material Cynthia Duk - Brasília: MEC, SEESP, 2006.

BRASIL. Ministério da Educação. Secretaria de Educação Especial. Política Nacional na Perspectiva da Educação Inclusiva. Brasília: MEC, 2008.

BRASIL. Resolução CNE/CEB n. 04 de outubro de 2009. Institui Diretrizes Operacionais para o Atendimento Educacional Especializado na Educaşão Básica, modalidade Educação Especial. Ministério da Educação, Conselho Nacional de Educação, Câmara de Educação Básica.

BRASIL. Lei n. 9.394, de 20 de dezembro de 1996: Lei de diretrizes e bases da educação brasileira. Brasília: MEC, 1996.

CANEN, Ana. Universos culturais e representações docentes: subsídios para a formação de professores para a diversidade cultural. Educaşão e Sociedade, ano XXII, n. 77, Campinas, CEDES, dez. 2001.

CAPELLINI, Vera Lúcia Messias Fialho. Práticas educativas: ensino colaborativo. In: CAPELLINI, Vera Lúcia Messias Fialho (org.). Práticas em educação especial e inclusiva na área da deficiência mental. Bauru: MEC / FC / SEE, 2008.

CARVALHO, Rosita Edler. Educaşão inclusiva: com os pingos nos "is". 11. ed. (revista e atualizada). Porto Alegre: Mediação, 2016. 
CENTRO DE ESTUDOS EDUCAÇÃO E SOCIEDADE. Educação Indígena na Escola. Cadernos CEDES, n. 19, dez. 1999.

CAVALCANTE. Escola Estadual Professor Edinilson Lima, Projeto Político Pedagógico, 2018.

DEVILLE, Gabriel. Tradução e condensação de Karl Marx: O capital. 3. ed. 2. reimp. Bauru, São Paulo: Edipro, 2013.

FRIEND, Marilyn, COOK, Lynne. Collaboration as a predictor for success in school reform. Journal of Educational and Psychological Consultation, 1 (1), p. 69-86, 1990.

GADOTTI, Moacir. Concepção dialética da educação: um estudo introdutório. 16. ed. São Paulo: Cortez, 2012.

HARGREAVES, Andy et al. Aprendendo a mudar: o ensino para além dos conteúdos e da padronização. Trad. Ronaldo Cataldo Costa. Porto Alegre: Artmed. 2002.

LÓ, Judith Eva Dupont. Uma escola para todos e para cada um: escola inclusiva, uma comunidade de aprendizes. Conjectura, v. 15, n. 1, jan./abr. 2010.

MAGALHÃES, Rosana Roth. O perfil do professor que atua na estadual de Educação Especial. Monografia (Pós-graduação Lato Sensu em Educação Especial) - União das Faculdades de Tangará da Serra, Boa Vista, 2003.

MORIN, Edgar. Os sete saberes necessários à educação do futuro. São Paulo: Cortez: Brasília, UNESCO, 2011.

NÓVOA, Antônio. Inovação e História da Educação: Teoria e Educação. Porto Alegre: Pannonica, n. 6, 2001.

PIMENTA, Selma (org.). Formação de professores. Identidade e saberes da docência: saberes pedagógicos e atividade docente. São Paulo: Cortez, 2002.

REGO, Teresa Cristina. Vygotsky: uma perspectiva histórico-cultural da educação. 25. ed. Petrópolis, Rio de Janeiro: Vozes, 2014.

RORAIMA. PLANO ESTADUAL DE EDUCAÇÃO. (PEE/RR, 2014-2024). Imp. Brasília, 2015.

RORAIMA. Regimento Unificado para as escolas indígenas do sistema estadual de ensino. Boa Vista, 2011.

SKLIAR, Carlos. Pedagogia (improvável) da diferença: e se o outro não estivesse aî? Rio de Janeiro: DP\&A, 2003.

TARDIF, Maurice. Saberes docentes e formação profissional. Petrópolis, Rio de Janeiro: Vozes, 2007.

VYGOTSKY, Lev Semyonovich et al. Linguagem, desenvolvimento e aprendizagem. São Paulo: Ícone: Edusp, 1988. 


\section{Informações das autoras}

Selma Maria Cunha Portela

Secretaria de Estado de Educação e Desporto de Roraima

E-mail: portelagil@gmail.com

ORCID: https://orcid.org/0000-0001-6485-9904

Link Lattes: http://lattes.cnpq.br/8584559517405196

Roseli Bernardo S. dos Santos

Instituto Federal de Educação, Ciência e Tecnologia de Roraima (IFRR)

E-mail: roselibss2@hotmail.com

ORCID: http://orcid.org/0000-0001-6809-6174

Link Lattes: http://lattes.cnpq.br/4481929272240602 